\title{
AC 2008-781: BUILD IT: BUILDING MIDDLE AND HIGH SCHOOL STUDENTS' UNDERSTANDING OF ENGINEERING, SCIENCE AND IT THROUGH UNDERWATER ROBOTICS
}

Elisabeth McGrath, Stevens Institute of Technology

Susan Lowes, Teachers College, Columbia University

Peiyi Lin, Teachers College, Columbia University

Jason Sayres, Stevens Institute of Technology

Liesl Hotaliing, The Beacon Institute

Rustam Stolkin, Stevens Institute of Technology 


\title{
BUILD IT: Building Middle and High School Students' Understanding of Engineering, Science and IT Through Underwater Robotics
}

\begin{abstract}
Designing and building robots to perform a series of increasingly complex tasks in an underwater environment is the vehicle to engage, interest, and cultivate 36 middle and high schools in learning engineering, science and information technology. Using LEGO components and a hands-on, team-based, iterative design process, teachers and students learn how to build robots that must operate underwater in a three dimensional space. In building their robot to perform these tasks (proceed in straight line path across a pool, negotiate a slalom course, ascend/descend in a water column, and grab/deposit a wiffle ball into an underwater goal), they not only practice the engineering design process, but also learn the underlying science concepts that impact the performance of their robot, e.g., buoyancy, gear ratios, and mechanics. A one-week summer institute for teachers introduced them to the project goals and equipment, and the performance challenges their robots would face. A second week allowed teachers to pilot test the lessons with middle and high school students. "Teach Talks" and "Tech Talks" provided "just in time" learning resources for participants as they built and refined their robots. During the 2007-08 school year, teachers are implementing the lessons as part of their technology, physics, general science, or engineering courses in a range of implementation scenarios. This project, an NSF Information Technology Experiences for Students and Teachers (ITEST) grant, is aimed at motivating and preparing students, particularly from underrepresented groups, to pursue IT and engineering degrees and careers. A deliberate effort was made to enlist the participation of different types of teachers - general science, physics, engineering, technology education, and computer teachers-from a varied socioeconomic and academic group of schools across New Jersey in order to understand how the project can be implemented in a range of environments. Data from teacher and student surveys, student pre- and post-tests, and teacher follow-up surveys are being gathered and analyzed. The model and effectiveness of the summer institutes is described, as are the varying implementation models, challenges, and successful classroom strategies.
\end{abstract}

\section{Introduction}

BUILD IT is a three-year National Science Foundation-sponsored comprehensive ITEST (Information Technology Experiences for Students and Teachers) project whose overall goal is to increase students' exposure, experience, and career interests in science, engineering, and information technology. The project evolved through a collaboration between the Center for Environmental Systems at Stevens Institute of Technology and the Center for Innovation in Engineering and Science Education (CIESE), the Institute's primary K-12 outreach center. Previous implementations of the project have tested the concept and its efficacy with highachieving high school students during a residential summer engineering camp program, as well as through an elective one-credit design course aimed at exposing freshmen engineering students to hands-on engineering design earlier in their academic career. The ITEST project aimed to adapt these intensive efforts, which have taken place with self-selected engineering students, for suitability with a group of socio-economically, academically, and ethnically diverse middle and 
high school students and within the confines of regular school-day courses, not as an extracurricular or club activity. Such vertically integrated curricular innovation is being tested as an effective model of engaging a wide spectrum of students - in terms of age, maturity, and environment - through the adaptation of a single, intrinsically-motivating, hands-on engineering design project. ${ }^{1}$

The vehicle to engage students is an engineering design challenge utilizing LEGO materials, microcontrollers, sensors and sensory data, and communication technologies to build robots which perform a series of increasingly sophisticated and complex tasks in an underwater environment. Using a discovery-based and collaborative design process to design and build both remotely operated, wire-guided vehicles (ROVs) in the first year, and then programmable autonomous underwater vehicles (AUVs) equipped with sensors in the second year, students will experience and learn experimental design, motion and forces, balanced and unbalanced forces, rotational motion, machines, gear ratios, mechanics, buoyancy, electrical circuits, programming, and communications technologies. It is posited that they will also gain hands-on skills, expertise, and understanding of IT tools and concepts consistent with ITEA Standards for Technological Literacy, ISTE standards, and 21st century workforce skills. ${ }^{2,3,4}$

Particular emphasis has been made to enlist schools with large populations of disadvantaged students. Seventy-one middle and high school teachers and 144 students representing 36 geographically, socio-economically, and ethnically diverse schools are directly participating in this three-year initiative. In total, approximately 2,625 middle and high school students will be impacted by BUILD IT classroom activities over the lifetime of the project.

This paper will describe the goals, activities, and impact of the curriculum development, teacher and student summer institutes, and preliminary classroom implementation results for the first phase of the project: designing the wire-guided, underwater ROV and controlling it to perform the initial set of performance challenges related to maneuvering around the pool and collecting/placing wiffle balls in a goal.

\section{BUILD IT Program and Learning Goals and Activities}

In meeting the ITEST program goals to provide more students with experience and motivation to pursue IT and STEM study and careers, the BUILD IT project focuses on three key constituencies: (1) middle and high school teachers; (2) their students; and (3) guidance counselors. In addition, we have sought to engage parents and the greater school community, as well as the media, to showcase the learning and motivational impact of this project on students and to generate support and greater participation for expansion and follow-on efforts.

The underwater robotic design challenges present unique science and engineering learning opportunities. Robotics has been demonstrated as an effective vehicle for discovery-based learning. ${ }^{5,6}$ However, the unique feature of BUILD IT — the challenges associated with building and controlling robots in an underwater environment-introduces opportunities to learn new science topics, such as buoyancy, which are not typically a part of robotics projects. In addition, controlling a robotic vehicle in a 3D space is more complex (six degrees of freedom) as compared with the three degrees of freedom of motion of a wheeled vehicle on a 2D planar 
surface. Students experiment and test designs and in the process are exposed to various engineering and science topics including propulsion, drag, buoyancy and stability, as well as gearing, torque, speed, and thrust. Practical construction problems, such as how to waterproof electrical components, call upon participants to develop their problem-solving skills. The use of LEGO materials is a particularly effective tool, as has been documented elsewhere, ${ }^{7,8}$ to allow rapid prototyping, testing, and redesign.

Teams of two teachers from 36 middle and high schools and 72 students participated in summer institute activities in Phase 1 (July-August 2007). During the 2007-08 school year, each school will implement the project, consisting of at least 20 regular class periods, with a group of at least 20 students. Teachers represent middle and high school science, technology, mathematics, and specialized (e.g., robotics) disciplines, and are implementing the project in the context of a variety of these courses. Data is being collected from a variety of sources to assess student learning of science and engineering content and skills, as well as career awareness and interest/motivation in STEM and IT.

\section{Project Activities}

\section{$\underline{\text { Recruitment }}$}

A statewide recruitment effort to engage 36 schools representing geographically, socioeconomically, and academically diverse students, was launched during the first year of the project. A wide spectrum of school settings was desired in order to assess the efficacy of the project in diverse settings. Particular effort was made to enlist schools with high percentages of low SES and African-American and Latino populations. Several orientation sessions were held to acquaint school administrators, as well as prospective teacher participants, with the project's potential benefits and responsibilities. Three issues arose during recruitment efforts:

- Time needed to successfully implement the curriculum (approximately 20 class periods)

- Requirement for two teachers to participate in all activities

- Logistical challenges involving placement of the pool needed for implementation

Efforts to recruit schools were assisted by interest in robotics, resulting, in part, from the momentum of the U.S. FIRST competition. Some schools, particularly those from low SES communities which are pressured to improve student scores on high stakes state tests, were reluctant to devote at least 20 class periods - the time required to accomplish the activities-to the project. The opportunity to receive the equipment package, valued at approximately $\$ 1,000$ and sufficient to equip a class of 20 students to implement the project, as well as the intensive professional development component of the program, were viewed as inducements to school participation. After an extended recruitment period, as well as several late substitutions and changes due to personnel and district funding issues, 71 teachers representing 19 middle and 17 high schools committed to the project. A contract documenting project commitments (summer institute attendance, conditions for stipends, attendance at school year professional development days, support for implementation, conditions for receipt and upkeep of the \$1,000 equipment package provided to each school team) and signed by participating teachers and principals, served as a record of the respective responsibilities of participating teachers and administrators. 
Figure 1 shows the grade level, location, and SES status of the participating schools. A wide range of geographic and socioeconomic diversity is included in the participant roster.

In addition to recruitment, Year 1 activities focused on development/adaptation of the curricula and planning and delivering the summer institute.

\section{$\underline{\text { Summer Institute }}$}

In order to enable teachers to absorb and assimilate a significant amount of new material, a scaffolding approach was used: during the first summer, the focus was on mechanical design of wire

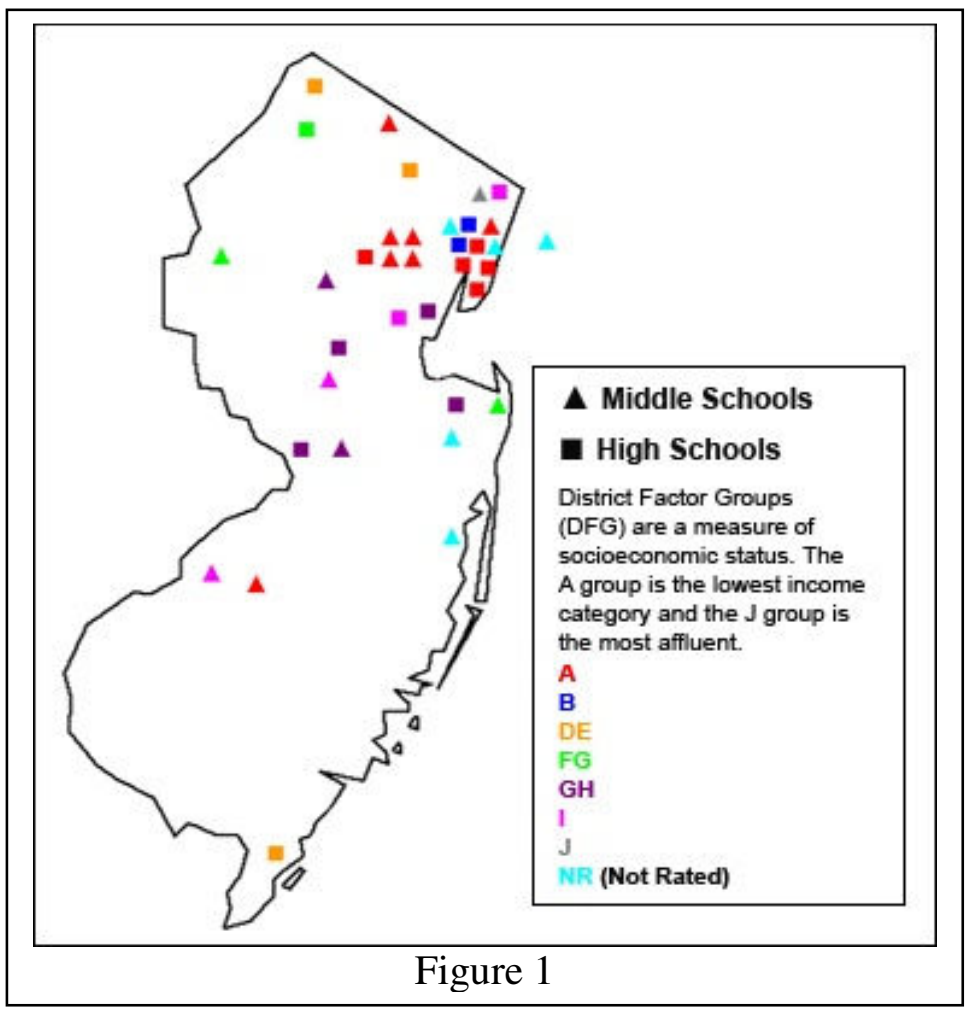
guided ROVs that would operate underwater, and in the second summer (2008), on programming to create Autonomous Underwater Vehicles (AUVs). To ensure that teachers are confident using the materials themselves and with students, the curriculum is delivered over two and a half years, with significant classroom support by project staff during implementation as well as a web site, discussion area, and online learning community to provide continuous assistance during the school year.

Two-week summer sessions were conducted twice to accommodate the large group of teachers and students with personal attention. Undergraduate students who had previously participated in the one-credit course served as technical assistants during the institutes. Week 1, the teacher institute, supported teachers in becoming acquainted with project materials, curricula, and design challenges. Two school teams formed a group of four to work on the series of design challenges leading to the culminating challenge - to create a vehicle with the ability to move in three dimensions through a pool and collect objects to place in a submerged bin in a timed competition.

The week was organized as a series of challenges (Table 1) that motivated participants (teachers in the first week and students, led by teachers, in the second week) to achieve intermediate learning goals. The institutes contained ample design and testing time, and were bolstered by "Tech Talks" and "Teach Talks" to highlight certain aspects of the challenges and their presentation in the classroom.

The Teacher Institute program appears in Table 2. 


\begin{tabular}{|c|c|c|}
\hline \multicolumn{3}{|c|}{ Table 1} \\
\hline $\begin{array}{l}\text { Straight Line } \\
\text { Challenge }\end{array}$ & $\begin{array}{l}\text { Use a single motor to build a } \\
\text { vehicle that can travel the diameter } \\
\text { of the pool on the surface as } \\
\text { quickly as possible; optimize } \\
\text { gearing to achieve best propeller } \\
\text { speed. }\end{array}$ & 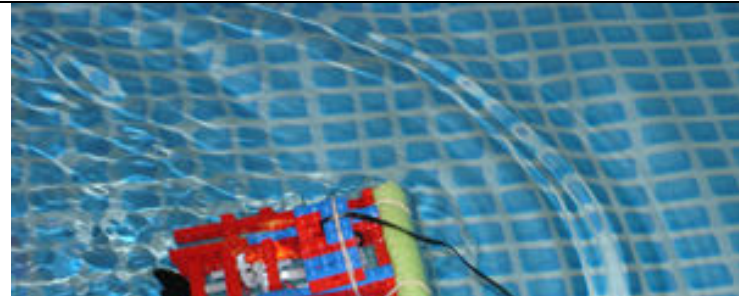 \\
\hline $\begin{array}{l}\text { Slalom } \\
\text { Challenge }\end{array}$ & $\begin{array}{l}\text { Use a second motor to enable } \\
\text { steering; maneuver on surface to } \\
\text { complete a slalom course around } \\
\text { two buoys in shortest time. }\end{array}$ & 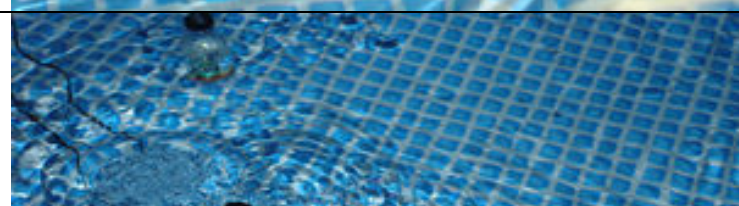 \\
\hline $\begin{array}{l}\text { Submerge } \\
\text { Challenge }\end{array}$ & $\begin{array}{l}\text { Use a third motor and other } \\
\text { materials to control the vehicle's } \\
\text { buoyancy in order to descend and } \\
\text { rise vertically in water }\end{array}$ & है \\
\hline
\end{tabular}




\begin{tabular}{|l|l|}
\hline $\begin{array}{l}\text { Grabber } \\
\text { Challenge }\end{array}$ & $\begin{array}{l}\text { Design a motorized mechanical } \\
\text { manipulator which can grasp } \\
\text { specified objects; build an } \\
\text { electrical control system which } \\
\text { uses four 4 switches to control } 4 \\
\text { motors (left, right, vertical, } \\
\text { grabber); each switch must have } 3 \\
\text { positions (forwards, backwards, } \\
\text { off). }\end{array}$ \\
\hline $\begin{array}{l}\text { Final } \\
\text { Challenge }\end{array}$ & $\begin{array}{l}\text { Combine the products of previous } \\
\text { challenges to produce a vehicle } \\
\text { which can retrieve the greatest } \\
\text { number of objects from the bottom } \\
\text { of the pool within a specified } \\
\text { period. Objects must be deposited } \\
\text { in bins at various depths in the } \\
\text { water to score points. }\end{array}$ \\
\hline
\end{tabular}

\begin{tabular}{|c|c|c|c|c|c|}
\hline \multicolumn{6}{|c|}{ Table 2} \\
\hline \multicolumn{6}{|c|}{ Teacher Institute } \\
\hline & Monday & Tuesday & Wednesday & Thursday & Friday \\
\hline $\begin{array}{l}\text { 9:00 - } \\
10: 00\end{array}$ & $\begin{array}{l}\text { Check-in, } \\
\text { Outline today's } \\
\text { activities } \\
\text { What's in the } \\
\text { box? } \\
\text { Tech Talk - } \\
\text { "Propulsion" }\end{array}$ & $\begin{array}{l}\text { Review } \\
\text { previous day's } \\
\text { activities, } \\
\text { Outline } \\
\text { today's } \\
\text { activities } \\
\text { Tech Talk - } \\
\text { "Steering" }\end{array}$ & $\begin{array}{l}\text { Review } \\
\text { previous day's } \\
\text { activities, } \\
\text { Outline today's } \\
\text { activities } \\
\text { Tech Talk - } \\
\text { "Electrical } \\
\text { control system" }\end{array}$ & $\begin{array}{l}\text { Review } \\
\text { previous day's } \\
\text { activities, } \\
\text { Outline today's } \\
\text { activities } \\
\text { Vertical } \\
\text { Motion } \\
\text { Challenge }\end{array}$ & $\begin{array}{l}\text { Review } \\
\text { previous } \\
\text { day's } \\
\text { activities, } \\
\text { Outline } \\
\text { today's } \\
\text { activities } \\
\text { Design Time }\end{array}$ \\
\hline & & & & Design Time & \\
\hline $\begin{array}{l}\text { 10:00 - } \\
\text { 11:00 }\end{array}$ & $\begin{array}{l}\text { Design Time } \\
\text { Or } \\
\text { Cable making }\end{array}$ & $\begin{array}{l}\text { Design Time } \\
\text { Or } \\
\text { Cable making }\end{array}$ & $\begin{array}{l}\text { Design Time } \\
\text { Or } \\
\text { Cable making }\end{array}$ & $\begin{array}{l}\text { Tour of a Lab } \\
\text { with short talk } \\
\text { by a researcher } \\
\text { Or } \\
\text { Design Time }\end{array}$ & Design Time \\
\hline $\begin{array}{l}\text { 11:00 - } \\
12: 00\end{array}$ & $\begin{array}{l}\text { Straight-line } \\
\text { Challenge }\end{array}$ & $\begin{array}{l}\text { Tour of a Lab } \\
\text { with short talk } \\
\text { by a researcher }\end{array}$ & $\begin{array}{l}\text { Tech Talk - } \\
\text { "Archimedes } \\
\text { principle, }\end{array}$ & $\begin{array}{l}\text { Tour of a Lab } \\
\text { with short talk } \\
\text { by a researcher }\end{array}$ & $\begin{array}{l}\text { Design Time } \\
\text { Teach Talk - }\end{array}$ \\
\hline
\end{tabular}




\begin{tabular}{|c|c|c|c|c|c|}
\hline & $\begin{array}{l}\text { Graduate } \\
\text { credit } \\
\text { requirements } \\
\text { and } \\
\text { registration }\end{array}$ & $\begin{array}{l}\text { Or } \\
\text { Design Time }\end{array}$ & $\begin{array}{l}\text { buoyancy and } \\
\text { vertical motion" } \\
\text { Design Time }\end{array}$ & $\begin{array}{l}\text { Or } \\
\text { Design Time }\end{array}$ & Debugging \\
\hline $\begin{array}{l}12: 00- \\
1: 00\end{array}$ & LUNCH & LUNCH & LUNCH & LUNCH & LUNCH \\
\hline $\begin{array}{l}1: 00- \\
2: 00\end{array}$ & $\begin{array}{l}\text { Teach Talk - } \\
\text { "Monitoring } \\
\text { vehicle design" }\end{array}$ & $\begin{array}{l}\text { Tour of a Lab } \\
\text { with short talk } \\
\text { by a researcher } \\
\text { Or } \\
\text { Design Time }\end{array}$ & $\begin{array}{l}\text { Tech Talk- } \\
\text { "Grabber" } \\
\text { Design Time }\end{array}$ & Design Time & $\begin{array}{l}\text { Final } \\
\text { Challenge }\end{array}$ \\
\hline $\begin{array}{l}2: 00- \\
3: 15\end{array}$ & $\begin{array}{l}\text { Design Time } \\
\text { Tech Talk - } \\
\text { "Stability in } \\
\text { Water" } \\
\text { Daily } \\
\text { Evaluation and } \\
\text { Wrap-up }\end{array}$ & $\begin{array}{l}\text { Slalom } \\
\text { Challenge } \\
\text { Teach Talk - } \\
\text { "Organizing } \\
\text { Materials" } \\
\text { Daily } \\
\text { Evaluation and } \\
\text { Wrap-up }\end{array}$ & $\begin{array}{l}\text { Design Time } \\
\text { Teach Talk - } \\
\text { "Classroom } \\
\text { Management" } \\
\text { Daily } \\
\text { Evaluation and } \\
\text { Wrap-up }\end{array}$ & $\begin{array}{l}\text { Teach Talk- } \\
\text { "Maintaining } \\
\text { Equipment" } \\
\text { Design Time } \\
\text { Daily } \\
\text { Evaluation and } \\
\text { Wrap-up }\end{array}$ & $\begin{array}{l}\text { Week } \\
\text { Evaluation } \\
\text { and } \\
\text { Wrap-Up }\end{array}$ \\
\hline
\end{tabular}

A "just-in-time" learning approach to technical content was modeled through the inclusion of "Tech Talks," brief lecture/demonstrations on topics such as stability, gearing, propulsion, electrical circuits and control panel design, buoyancy and Archimedes principle, grabbers, graspers, and manipulators. ${ }^{9}$ In addition, research applications of underwater robotics, oceanographic phenomena, IT and advanced communication technologies, and other research conducted at Stevens, were presented through guest lectures by researchers in order to provide participants with perspective on applications and careers.

"Teach Talks" helped teachers strategize about turn-keying the lessons with students. Among the key topics in the Teach Talks was the organization of materials, maintaining equipment, and classroom management.

Immediately following the first Teacher Institute, a one-week Student Institute was held, which paralleled, in content and format, the previous week's program. This institute enabled teachers to gain confidence teaching the materials by piloting them with a small group of students. This educational laboratory experience was supported by faculty, staff and student assistants, and allowed teachers to better plan for school year implementation, and to simply figure out what works with their students. 


\section{Evaluation of Summer Institute}

The two summer institutes were evaluated through daily surveys and one final end-of-institute survey, for both teachers and students. The daily surveys were not only used to assess the effectiveness of that day's activities but to adjust the activities on the following day-for instance, by adding explanations, discussing issues raised by the teachers, etc. The overall ratings for the first institute were high-- 4.6 out of 5 for teachers at the end of their first week and 4.8 for students at the end of their week. The evaluations for the first week of the second teacher institute were even higher ( 4.8 out of 5), in part due to changes that were made to take into account issues of pacing raised by the participants in the first institute. The teacher ratings for the second week (with students) were slightly lower (4.1 out of 5 for the both the first and second institute), in part because teachers had already mastered the material and because it contained fewer hands-on activities for teachers. As a result, the teachers' second week next summer will have more activities designed specifically for the teachers in the second week.

During the first week of the institute, the teachers worked in groups of four and, during the second week, the students did the same, modeling what would happen in their classrooms. Both the teachers during the first week and the students during the second week faced problems with group work, and considerable time was spent discussing these issues. As we will see below, this practice experience affected how the teachers subsequently organized the work in their own classrooms.

\section{$\underline{\text { School Year Professional Development }}$}

Research shows that material learned in summer institutes is more likely to be implemented in the classroom when followed up with additional support, including additional professional development sessions, classroom visits, and telephone and online conversations. ${ }^{10,11}$ Two professional development days - one in the fall semester and one in the spring semester-were one means of providing such support during the implementation process. To reduce travel time, the fall day was offered at two sites on two different days. This workshop focused on refreshing teachers' content knowledge, reviewing curricular resources, sharing pedagogical strategies and challenges; and showcasing effective implementation scenarios. Several teachers delivered PowerPoint presentations with highlights, challenges, and lessons learned. A number of teachers shared additional curricular materials and assignments they had developed to enrich the implementation. A portion of the day was devoted to a hands-on activity, waterproofing motors, which had been identified as a problem by several early implementers.

\section{Evaluation of School Year Professional Development}

These professional development days were very well received, with 98 percent of the attendees reporting that they either "Strongly Agreed" or "Agreed" that the trainer was well prepared, that the handout materials were clear, and that the session purpose and objectives were clearly stated. More than 90 percent agreed that the training met their expectations and that the material was useful and relevant to their needs. Teachers like to learn from other teachers, and the teacher-led presentations and demonstrations were particularly appreciated. 


\section{Other Sources of Implementation Support}

In addition to formal workshops as a means of supporting implementation, project staff visit each teacher at least once during the project to troubleshoot problems, share effective strategies developed by other teachers, and gather information on successes and unanticipated challenges. Participating schools identified a wide range of implementation schedules, based on course scheduling and other considerations, including weather conditions and placement of the pool necessary for testing designs and the final challenge. The fact that participating schools implemented the lessons at different times during the school year allowed instructors to visit all schools at least once, and often several times, during the classroom implementation period, and for the later implementers to benefit from lessons learned by those who implemented in the fall.

An online learning community, including a web site containing curricula and other instructional support materials, student assessments and other resources, as well as an email listserv, and webbased discussion forum, are also providing a vehicle to share project information, effective approaches, and lessons and engage colleagues in troubleshooting specific problems.

\section{Evaluation of Other Sources of Implementation Support}

The teachers also found the support from project staff played an important role in their being able to successfully solve the problems they encountered as they began to implement the curriculum. They referred to the project website, welcomed visits from project staff, and got help via email as well.

Eight of the ten teachers who have implemented the curriculum to date also felt that support from their own administration had been very important to the success of the project. This support has included allocating space for the pools, money for additional equipment, and time off for professional development.

\section{Classroom Implementation}

Although the teachers had only committed to implementing the curriculum with 20 students, many reported that they planned to use it with all of their classes. However, because each school has only a limited amount of equipment and because each teacher needs time to work out the logistics in his/her school, some began with either one class or a selected group of students and then expanded to their regular classes or to more students. During the fall semester of 2007, teachers in 24 of the 36 schools had begun to teach the curriculum and by early January 2008, 10 had completed at least one round and returned the post-implementation survey.

Most of those who had completed an implementation reported that they had included the curriculum in their existing courses, replacing or supplementing existing material, and therefore taught it every day, but the number of weeks they devoted to it ranged widely, from five to twelve. Most preferred to do the first implementation with students who were likely to be interested or with classes that were particularly well-behaved, but even these students were generally academically heterogeneous. These teachers also reported that very few of their 
students had prior experience with LEGO robotics, and those who did were mostly high school students.

\section{Preliminary Evaluation Findings}

Surveys were administered to teachers, who were asked to assess the extent to which the curriculum had engaged the students and strengthened various skills, using a five-point scale, with 5 being the highest. The highest rankings were for student engagement, closely followed by working in groups and learning the principles of buoyancy:

\begin{tabular}{|l|l|}
\hline Engaged the students & 4.70 \\
\hline Helped them learn to work well in groups & 4.50 \\
\hline Helped them learn the principles of buoyancy & 4.50 \\
\hline Helped them gain presentation skills & 4.33 \\
\hline Helped them learn the principles of gears & 4.30 \\
\hline Helped them learn the principles of iterative design & 3.90 \\
\hline Reinforced math skills & 3.90 \\
\hline Helped them learn the principles of electricity & 3.50 \\
\hline Gave them new math skills & 3.11 \\
\hline
\end{tabular}

Some of teachers who had completed the survey wrote about the additional benefits. These revolved around the challenge of solving problems:

"They enjoyed the open ended problem, working together in different groups, and the freedom to take chances and not fail."

"Students were motivated not to give up. They were eager to continue even if they were struggling."

"It gave them a great first-hand idea of problem-solving techniques and how to apply them. They also learned that you don't always have to be successful and that sometimes you can still benefit and learn even when not successful."

During implementation, all these teachers had had their students work in groups or teams, generally with three or four students per team. Almost all had had to resolve problems with personality conflicts or with one person dominating. Following is one teacher's description of managing group dynamics in her class. Although her description is lengthier than most, the problems and her resolution were typical:

The passive students just watched as the others worked, took notes, and helped clean up. The boys ignored the two girls who just watched and communicated on their own. The other two girls were fine and integrated into their groups. So I created an all-girl group for one challenge. The quiet girl was still passive but did start to 
add value. The girl group had a poor showing in the final challenge

since their male builder was transferred and they did not get the gearing to work properly so their robot was slow and not reliable.

We encouraged "consultants" so if one group was having a problem, we opened it up for a class discussion or a knowledgeable person from another team would help them troubleshoot the problem. Most of the problems were with students' passivity while the active students took over the projects.

As noted above, time had been spent during the summer institutes discussing issues surrounding group work and this was reflected in the organization of the curriculum in the classroom. When asked if their experience with group work during the summer institute had led them to make any changes in how they organized or facilitated their students' group work, nine of the ten teachers reported that they had done at least one (and generally most) of the following: reduced the size of the groups in the early challenges to allow for more students to engage in hands-on work; assigned roles so that all students had work to do; chose the group members carefully to balance personalities and academic strengths; and intervened quickly when problems arose.

While only four of the ten teachers reported that they built in a discussion of the design process, six of the ten said they had explicitly integrated a discussion of careers.

Only four of the ten saw gender differences when teaching this curriculum, and three of the four were middle-school teachers. They found the girls less willing to build and the boys less willing to let them do so. They attributed this to the fact that the boys were not only more aggressive but were more familiar with the LEGO sets. However, they also reported that when encouraged, the girls became very interested in the design process. Here is how one teacher described the difference:

Girls let the boys build the LEGOs since the boys played with them as youths and had greater prior knowledge. The girls were often the recorders for their groups and did well in the wiring and electronics section, where most of the students had no experience. With time, they were more comfortable building with the LEGOs. They also created smaller, more compact robots. With the start of the second AUV section, their confidence level increased and they were now "equals" with the boys with prior LEGO-building experience. For some, their strength is in designing software and creating presentations and they chose to continue in those roles.

\section{$\underline{\text { Case Studies }}$}

Two examples, one from a middle school teacher and one from a high school teacher, show how the curriculum can be successfully adapted to very different situations.

The middle school is a suburban school in an affluent community. The participating teacher has 26 years of classroom experience, an undergraduate degree in Industrial Arts and Technology, and state teaching certifications in Industrial Arts K-12, Elementary K-8, and Middle School Math HQT. Industrial Arts and Technology is required for all seventh graders. Since he taught 
Industrial Arts/Technology, he relied on his fellow teacher in the project to help with teaching the science concepts. He taught the curriculum to one class every day for ten weeks.

Despite the fact that the school is a relatively good one, the students in this class were academically heterogeneous, ranging from special education students to slow learners to those the teacher considered not sufficiently challenged intellectually most of the time. The students' own estimation of their abilities was in line with this, with about 70 percent reporting that they found school either "easy" or "very easy," but a number reporting that they only received Cs in science and math.

Almost all (90 percent) of the students reported that they had already studied forces and motion, but only half reported that they had learned about electrical switches, only one-third had learned about gears, and only one or two reported that they had studied buoyancy. Assessments were drawn from a source on buoyancy ${ }^{12}$, and supplemented with additional items that were developed by project faculty. The results of the pre-assessments corroborate this. Each assessment had three or four questions, depending on the subject, and although a higher percentage of students got more correct answers for gears than for the other two assessments, none of the results were showed a full understanding of the concepts involved:

Number of questions answered correctly on each pre-assessment

\begin{tabular}{|l|l|l|l|l|l|l|}
\hline & $\begin{array}{l}0 \\
\text { correct }\end{array}$ & $\begin{array}{l}1 \\
\text { correct }\end{array}$ & $\begin{array}{l}2 \\
\text { correct }\end{array}$ & $\begin{array}{l}3 \\
\text { correct }\end{array}$ & $\begin{array}{l}4 \\
\text { correct }\end{array}$ & \\
\hline Gears & $9 \%$ & $35 \%$ & $26 \%$ & $26 \%$ & $4 \%$ & $100 \%$ \\
\hline Electricity & $27 \%$ & $\mathbf{6 4 \%}$ & $9 \%$ & n/a & n/a & $100 \%$ \\
\hline Buoyancy & $\mathbf{6 5 \%}$ & $30 \%$ & $5 \%$ & $0 \%$ & n/a & $100 \%$ \\
\hline
\end{tabular}

By the post-assessment, the number of questions answered correctly had increased on all the tests. Despite the fact that the teacher rated the curriculum highly in terms of teaching buoyancy, the results of the post-test show that this was still a concept that his students were struggling with:

Number of questions answered correctly on each post-assessment

\begin{tabular}{|l|l|l|l|l|l|l|}
\hline & $\begin{array}{l}1 \\
\text { correct }\end{array}$ & $\begin{array}{l}\text { correct } \\
\text { Gears }\end{array}$ & $\begin{array}{l}2 \\
\text { correct }\end{array}$ & $\begin{array}{l}3 \\
\text { correct }\end{array}$ & $\begin{array}{l}4 \\
\text { correct }\end{array}$ & \\
\hline Electricity & $4 \%$ & $4 \%$ & $26 \%$ & $39 \%$ & $26 \%$ & $100 \%$ \\
\hline Buoyancy & $5 \%$ & $23 \%$ & $\mathbf{7 3 \%}$ & n/a & n/a & $100 \%$ \\
\hline
\end{tabular}

This teacher was one of those who had used the experience of the summer institute to modify group work in the classroom. As he wrote in his post-implementation survey, "I thought the adults had trouble working in groups of four on one model, so I decided to start out with groups of two, so all the students were involved. I also knew to choose the groups carefully so one person wouldn't over-run the team and not wait too long to adjust the groups if there were major 
issues." He had also encouraged the girls to be involved in all aspects of the curriculum, including the building, and had quickly adjusted groups that appeared to be dysfunctional.

Each group also completed a design log in order to document their progress and reflect on their vehicle's performance. Below are two examples.
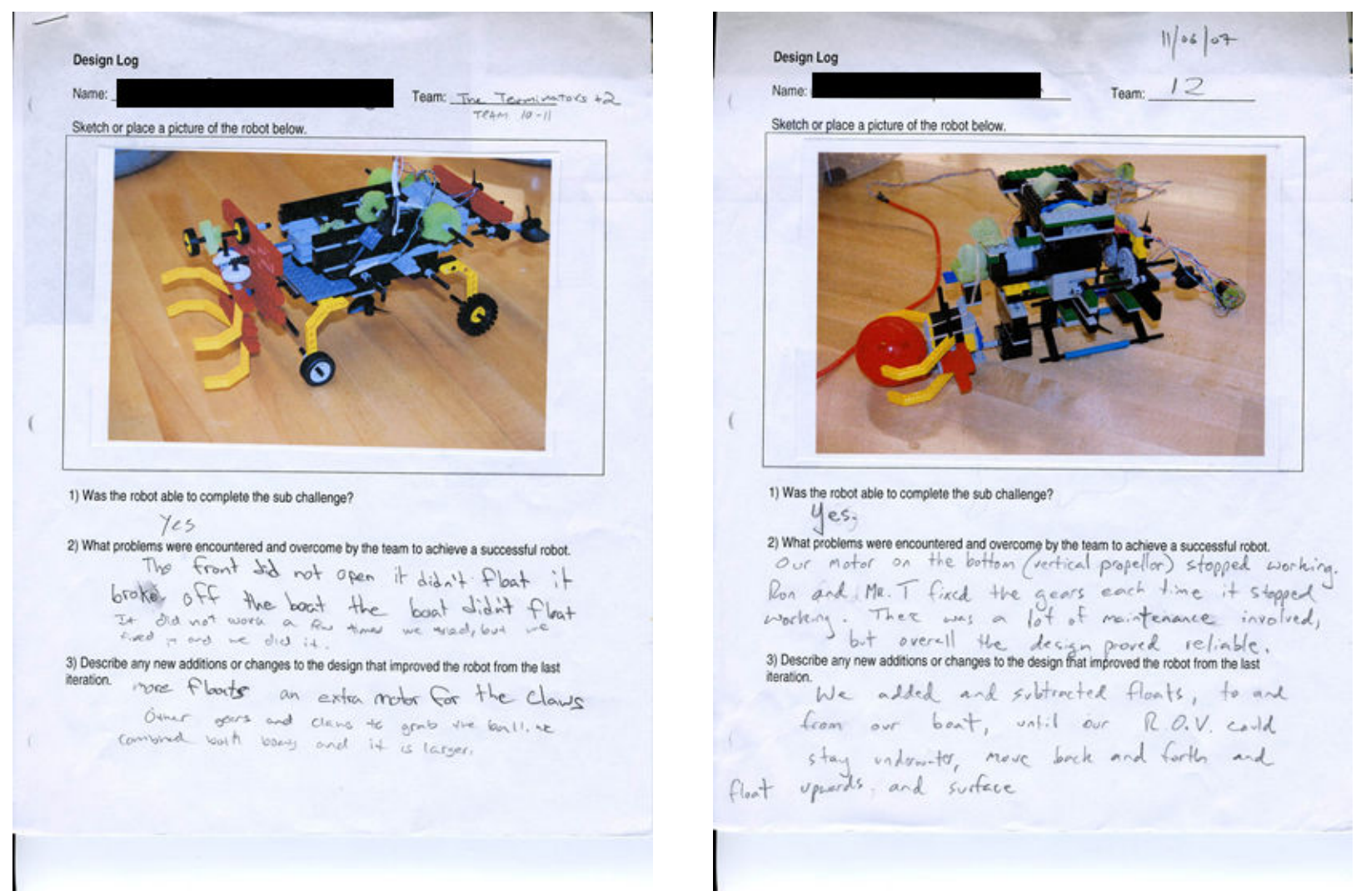

The high school was very different from the middle school: the student body is 70 percent Hispanic and 20 percent African American, and the community is in the lowest income ranking for a New Jersey school. However, the school has an engineering track and is involved in Project Lead the Way, and the teacher came to teaching after a career as an electrical engineer.

The first class that used the BUILD IT curriculum was made up of sophomores in a preengineering track, and it was taught for 100-minute periods every day for 12 days. Almost all (93 percent) of the students reported that they had previously studied electrical switches, 60 percent said they had learned about motion, approximately half had studied forces and buoyancy, and about one-third had studied gears and gear ratios.

Given this, it might be expected that these students would do much better on the preassessments. However, this was not the case, even with gears and electricity: 
Number of questions answered correctly on each pre-assessment

\begin{tabular}{|l|l|l|l|l|l|l|}
\hline & $\begin{array}{l}0 \\
\text { correct }\end{array}$ & $\begin{array}{l}1 \\
\text { correct }\end{array}$ & $\begin{array}{l}2 \\
\text { correct }\end{array}$ & $\begin{array}{l}3 \\
\text { correct }\end{array}$ & $\begin{array}{l}4 \\
\text { correct }\end{array}$ & \\
\hline Gears & $0 \%$ & $13 \%$ & $44 \%$ & $38 \%$ & $6 \%$ & $100 \%$ \\
\hline Electricity & $38 \%$ & $19 \%$ & $44 \%$ & N/A & N/A & $100 \%$ \\
\hline Buoyancy & $50 \%$ & $44 \%$ & $6 \%$ & $0 \%$ & N/A & $100 \%$ \\
\hline
\end{tabular}

Like the middle school students, these students did much better on the post-assessments. This teacher added an Electrical Challenge to the curriculum, which may account for the high scores on the electricity post-assessment, but her students (like the middle school students) had the most trouble with the concept of buoyancy:

Number of questions answered correctly on each post-assessment

\begin{tabular}{|l|l|l|l|l|l|l|}
\hline & $\begin{array}{l}0 \\
\text { correct }\end{array}$ & $\begin{array}{l}1 \\
\text { correct }\end{array}$ & $\begin{array}{l}2 \\
\text { correct }\end{array}$ & $\begin{array}{l}3 \\
\text { correct }\end{array}$ & $\begin{array}{l}4 \\
\text { correct }\end{array}$ & \\
\hline Gears & $0 \%$ & $0 \%$ & $6 \%$ & $56 \%$ & $38 \%$ & $100 \%$ \\
\hline Electricity & $6 \%$ & $6 \%$ & $\mathbf{8 8 \%}$ & N/A & N/A & $100 \%$ \\
\hline Buoyancy & $0 \%$ & $6 \%$ & $50 \%$ & $44 \%$ & N/A & $100 \%$ \\
\hline
\end{tabular}

This teacher had also learned from her experience during the summer institute and had organized her groups carefully. She had assigned roles and played a more active facilitating role than she had in the past.

The high school students kept design logs as well: 




Both these teachers found the curriculum fit well into their existing courses and both felt that it taught valuable skills in addition to concepts. Both felt that the hands-on aspect of the curriculum was motivating for their students. For the middle school teacher, there was also the additional important lesson that unsuccessful prototypes are not failures but steps toward a final solution.

\section{$\underline{\text { Additional Data Being Collected }}$}

In addition to the teacher surveys, which assess IT skills/IT career awareness and teaching practices/science curriculum, and the student surveys, which assess IT skills and knowledge of IT careers/interest in STEM subjects, guidance counselors in each school will be asked about guidance practice and IT career awareness. Both teachers and students will be surveyed at the end of this year and subsequent years, to track change over time.

\section{Next Steps}

In addition to continuing project implementation, classroom and online support, and collection of data, several key events are scheduled for spring 2008:

- Spring Professional Development Workshop: A required session to monitor project implementation, gather input to finalize parameters of the culminating competition, provide technical/content support, and review plans for the second summer's activities. 
- Guidance Counselor Event: A mandatory requirement for guidance counselors of all participating schools, this event will feature women and members of underrepresented groups who range from recent STEM/IT graduates to successful corporate and research executives. The goal is to change perceptions of the types of students who pursue these fields by guidance counselors.

- Underwater Robotics Competition and IT Symposium: Teams of five students per school will compete in a timed challenge. A keynote speaker from NASA with experience with robotic operations has been invited to give the keynote address.

\section{Summary}

Despite unavoidable challenges with recruitment, scheduling, and the logistical and practical considerations of placing a pool in a school setting over at least a four-week period, initial results from teachers and students who have participated in the BUILD IT project to date demonstrate that the project is having a positive impact on student learning of key concepts related to gears, electricity, and buoyancy. Preliminary teacher-reported data shows benefits to students' problem-solving abilities, persistence, collaboration skills, and presentation skills. Additional data will yield important information about the project's impact on student motivation and career interests in STEM and IT careers.

\section{Bibliography}

1. Stolkin, R., Hotaling, L., Sheryll, R., Sheppard, K., Chassapis, C., McGrath. E., "A paradigm for vertically integrated curriculum innovation - how curricula were developed for undergraduate, middle and high school students using underwater robotics. Proceedings of the International Conference of Engineering Education. 2007. Coimbra, Portugal.

2. International Technology Education Association (2000). Standards forTechnological Literacy: Content for the Study of Technology. http://www.iteawww.org/TAA/Publications/STL/Benchmarks.pdf.

3. International Society for Technology in Education (2002). Technology Foundation Standards for All Students. http://cnets.iste.org/students/s_stands.html.

4. Partnership for $21^{\text {st }}$ Century Skills (2007). Framework for $21^{\text {st }}$ century learning. http://www.21stcenturyskills.org/documents/frameworkflyer_072307.pdf.

5. Jaksic, N., Spencer, D., An introduction to mechatronics experiment: LEGO Mindstorms next urban challenge. Proceedings of the ASEE Annual Conference and Exposition. 2007.

6. Hotaling, L., Sheryll, R., Stolkin, R. "Discovery based learning in the engineering classroom using underwater robotics. Proceedings of the ASEE Annual Conference and Exposition. 2006.

7. Portsmore, M.D. and Rogers, C., Bringing Engineering to Elementary School. Journal of STEM Education. Vol 5. 2004.

8. Wang. E., LaCombe, J., and Rogers, C., Using LEGO Bricks to Conduct Engineering Experiments. Proceedings of the ASEE Annual Conference and Exposition. 2004.

9. Stolkin, R., Hotaling, L., Sheryll, R., Sheppard, K., Chassapis., and McGrath, E. (2007). A paradigm for vertically integrated curriculum innovation - how curricula were developed for undergraduate, middle and high school students using underwater robotics. International Conference on Engineering Education, Coimbra, Portugal..

10. Hawley, W.D., \& Valli, L. (1999). The essentials of effective professional development: A new consensus. In L. Darling-Hammond \& G. Sykes (Eds.), Teaching as the learning profession: Handbook of policy and practice (pp. 127-150). San Francisco, CA: Jossey-Bass.

11. Wenglinsky, H., \& Silverstein, S. C. (2006). The science training teachers need. Educational Leadership 64 (4), 
24-29.

12. Loverude, M., Kautz, C., and Heron, P., Helping students develop an understanding of Archimedes' principle. American Journal of Physics, Vol. 71, No. 11, November 2003. 